\title{
SERVING KING AND SULTAN: PAVAO GRGURIĆ AND HIS ROLE ON THE HUNGARO-OTTOMAN FRONTIER IN SOUTHERN BOSNIA, C. 1463-1477
}

\section{Michael Ursinus}

Heidelberg University

\section{ABSTRACT}

Pavao Grgurić, a Christian 'man of the sword' active during the transition period between the last years of the independent Bosnian kingdom and the beginning of Ottoman rule, was an influential office holder in the Livno and (later) Neretva regions who remained a Christian for his entire (visible) career. Being initially awarded as his timar a compact group of 14 villages (clearly a feudal complex) in the immediate vicinity of Hum fortress (near Podhum village south of Livno) which he was to guard, he was later given an aggregate timar worth at least three times that of a dizdar or fortress commander. This poses the question of his exact function and standing within the Bosnian dual regime during the period of early Ottoman rule in the province. Rather than being enslaved later by the enemy, he appears to have been arrested on demand of the Sultan himself. His career can be traced for the period between 1463 and 1477.

One of the most enigmatic figures on the south-western extremity of the OttomanHungarian border during the 1460 s and into the 1470 s is Pavao veled-i Grgur, alias Pavao Grgurić. He is believed by the late Ahmed A. Aličić, the editor cum translator of the earliest summary survey register for the sanjak of Bosna of 1468/69, to be the commander (dizdar) of Hum fortress. With his company of guardsmen of Hum fortress (sa skupinom čuvara grada Huma) being stationed inside the fortress (koji se nalaze u tvrdavi), they would watch over the fortress known as Hum in the district of Livno (cuvaju tvrdavu zvanu HUM u nabiji Hlivno) by the time of the survey. Being rightly intrigued by the fact that Pavao is not registered as the dizdar of Hum fortress amongst his men, Aličić goes on to say: "Why this fact is not recorded I don't know. I think that the reason for this is that the troops (stražari) within the fortress were not included in the timar organization. It may also be that the control over the fortress was given to Pavao, son of Grgur, who probably handed over the fortress [of Hum], while the others are not even mentioned despite the fact that the verb 'to watch' is used in its plural form." According to Aličić, not only was the fortress of Hum handed over to the Ottomans by Pavao Grgurić (a fact stated this time without any qualifying 'probably'), but also that of Travnik. ${ }^{2}$

$1 \quad$ Ahmed A. Aličić, Sumarni popis sandžaka Bosna iz 1468/69. godine (Mostar, 2008), 195, footnote 2723 .

2 Loc. cit., 100 and footnote 1504 
Pavao Grguric, who never converted to Islam during his time in Ottoman service (according to Aličić he served as a timariot between 1463 and 1477 when he was finally taken prisoner [bio zarobljen]), ${ }^{3}$ clearly was a figure of some standing within the Ottoman ranks, but he must already have held high positions within the military of the Bosnian kingdom if it is true that he was instrumental in the (peaceful) surrender to the Ottomans of at least two fortresses.

It cannot be the aim of this short contribution to chase the 'needle in the haystack' by means of a thorough investigation into the diverse and scattered Slavic, Latin and Ottoman Turkish documentation on the transition from Bosnian to Ottoman governance just for the sake of finding a few more details about the identity and role of our protagonist during the third quarter of the $15^{\text {th }}$ century, ${ }^{4}$ however much of a desideratum a comprehensive case-study on any better-documented individual might be who, in his career, traverses the caesura between pre-Ottoman and Ottoman rule. ${ }^{5}$ Instead, the (limited) aim of this presentation is to question some of the assumptions and readings put forward by the editor/translator of the icmal or synoptic tahrir defteri O.76 from the M.Cevdet kütüphanesi İstanbul Büyükşehir Belediyesi Atatürk Kitaplığı which, according to Aličić, was being started between 26 January and 4 February and completed between 4 and 14 April $1469 .{ }^{6}$ It is believed that only on the basis of a sound interpretation of the evidence in 0.76 , and a discussion of its principal implications, can any future (more comprehensive) inquiry be successful.

In order to facilitate the later discussion of details, a translation is given here of the text (itself a translation from the Ottoman original) concerning the fortress of Hum and its assumed commander (dizdar), Pavao Grgurić, as presented by Aličić in his Sumarni popis (p. 195f.):

\section{Loc. cit.}

4 The only independent reference to Paul Gregurić (Gregorich) known to me was found recently by Davor Salihović in a codex from the Zadar archives (HR-DAZD-16, kut. 14, 30/3, fol. $51 \mathrm{r}$ ) quoting a civil court case from Split, testified January 1470. Here, according to Salihović, the castle of Hum is described as a stronghold 'which belongs to this Paul', brother of Stephen Gregurić based in Neretva district. Salihović suggests that the Gregurić (Gregorich) brothers may have been Vlachs: Davor Salihović, "Definition, Extent, and Administration of the Hungarian Frontier Toward the Ottoman Empire in the Reign of King Matthias Corvinus, 1458-1490," (unpublished PhD thesis, Magdalene College, Cambridge, 2020), p. 98.

5 Another such individual would be Vladislav, 'deputy' (kethüda) of the Bosnian king in his territories. Several entries in defter O.76 testify to his importance: fols. 49b, 59a, 61b, 62b, 119a-b. Cf. Aličić, Sumarni popis, 172f., footnote 2441.

6 Aličić reads the word 'ibtida' in the datatio as a term to indicate the first ten days (evail) and 'intiha' as a synonym for 'evahir', the last ten days of a given month: Aličić, Sumarni popis, XV. 
(fol. 132a) Timar of Pavao, son of Grgur

They guard the fortress by the name of HUM in the nabiye of Hlivno village BUŽANI [BUŽANIN], belonging to Livno, empty

village VUČEVIĆ [unidentified], ${ }^{7}$ belonging to the aforementioned, empty

village MIŠI [MIŠI], belonging to the aforementioned, empty

village REŠETAR [unidentified], belonging to the aforementioned, empty

village KARAČIKIT [KARAČIĆ], belonging to the aforementioned, empty

village ORAŽANI [unknown], belonging to the aforementioned, empty

village BANIĆ [unidentified], belonging to the aforementioned, empty

village PODHUM [PODHUM], belonging to the aforementioned, empty

village RAKOVICA [unknown/unidentified], belonging to the aforementioned, empty

village ČRČINA [unknown/unidentified], belonging to the aforementioned, empty

village ŠUŠNIĆ [ŠUŠNJIĆI], belonging to the aforementioned, empty

village BILA [BILA], belonging to the aforementioned, empty

village $\operatorname{ORL}(\mathrm{J}) \mathrm{A}$ [unknown/unidentified], belonging to the aforementioned, empty

village $\mathrm{ZABRADE}$ [unknown/unidentified], belonging to the aforementioned, empty

altogether villages $14 .^{8}$

The secondary entry in defter $\mathrm{O} .76$ concerning Pavao Grgurić is presented by Aličić in the following way (p. 100f.):

(fol. 59b) Timar of Timurtaš, one of the sons of sipahis:

This timar has been united with that of Davud, brother of Skender voyvoda, who is recorded on the opposite page, and by means of a

\footnotetext{
Many more of these villages have in the meantime been convincingly identified and put on the map by Tomislav Perković, "Livanjski kraj u doba rane osmanske vladavine", CLEUNA 1 (2014): 284-380; here: 320ff. For Pave sina Grgureva cf. 349. For the (final) Ottoman conquest of Livno in 1480 now see my contribution in CLEUNA 4 (2021), pp. 97 - 107 entitled "Ivan Ljubunčić, Frančesko Čubranić i Matij Hrvat[inić]: Davud-pašini livanjski ratni zarobljenici iz godine1480."

8 Aličić, Sumarni popis, $195 f$.
} 
ruler's order given to Pavao Grgurić who surrendered the strongholds of Hum and Travnik.

After the aforementioned was taken prisoner, this village was, by means of an imperial order, given to Haydar on condition that he serves in the field. Istanbul, 23 Zilkade in the year 881 .

village HOMOLJE

households 120, unmarried 15

Income 16.161

He personally is bürüme, with 5 cebelü, 1 gulam and 1 tent. ${ }^{9}$

There are in particular three instances where I find it difficult to follow the editor/translator's reading and/or interpretation of the original wording in $\mathrm{O} .76$ of which a scanned copy prepared by the Kütüphane ve Müzeler Müdürlüğü (Atatürk Kitaplığ 1 ) in Istanbul is at my disposal:

(1) "They guard the fortress by the name of Hum": Aličićs use of the plural in the second sentence of the first passage cannot be maintained: The original has the phrase: "Timar-i Pavao veled-i Griğur Hlivno nabiyesinde Hum nam kale bekler", which clearly ends with a verb in the singular. Its plural form would be 'beklerler'. Consequently, there remains no base for assuming that it was Pavao Grgurić, together with a group of guardsmen of Hum fortress being stationed inside the fortress, who watched jointly over the fortress known as Hum in the district of Livno, let alone in the function of dizdar: ${ }^{10}$ Nowhere in 0.76 is Hum, unlike many other fortresses in the sanjak of Bosna, listed as a fortress complete with fortress personnel (mustahfizan) under the control of a dizdar or 'commander.'11 And while according to Aličić the (exceptional) maximum prebendal income of a dizdar at this period is 8,881 akçe derived from up to eight villages, ${ }^{12}$ the timar of Pavao Grgurić comprises 14 villages with no actual income recorded at the time of the survey at all. His (later) timar in Homolje village, which was combined with that of Davud, brother of Skender voyvoda, to supply him with sufficient means, was to assure him an income of over 27,000 akçe-more than three times the absolute maximum for a contemporary Bosnian dizdar. What follows from this is that Pavao Grgurić was hardly a mere dizdar, certainly not a conventionally remunerated dizdar of Hum fortress with a standard outfit of fortress personnel stationed there. There simply is no evidence for either in O.76.

\footnotetext{
Aličić, Sumarni popis, $100 \mathrm{f}$.

10 Atatürk Kitaplığı, Istanbul. Survey register O.76, fol. 51a however records a dizdar of Livno, yet for the period after 25 Cumadiyülahir 879 (6 November 1474): Aličić Sumarni popis, 84.

11 Aličić Sumarni popis, 163-242.

12 Aličić Sumarni popis, 227, footnote 3140. For a dizdar receiving his income from eight villages see p. 186.
} 
(2) Did Pavao Grgurić surrender to the Ottomans the fortresses of Hum and Travnik? This question refers back to the second reference in O.76 to Pavao Grgurić quoted above. While the name 'Travnik' seems clearly written on fol. $59 \mathrm{~b}$ of the original text (albeit without diacritical marks), the name 'Hum' (equally without diacritics) is not. The final letter is missing its 'tail' to form a properly executed 'mim'; in addition, it seems to come as a loop rather than a filled-in circular 'head' of the letter. Rather than constituting the last letter of the name 'Hum' it seems to consist of two conjoined letters reading 'cim'-'he' or 'çim'-he', suggesting the place-name of $\mathrm{H}$ (v)oça (an early spelling of modernday Foča). Compared with other references to Foča (invariably given with diacritical marks) elsewhere in defter $\mathrm{O} .76,{ }^{13}$ either spelt ' $\mathrm{H}(\mathrm{v})$ oça' or ' $\mathrm{H}(\mathrm{v})$ oca' (see below), the closeness between all three becomes evident:

O.76, fol. 59b, from derkenar, thus without diacritical marks:

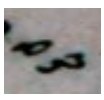

O.76, fol. 36a, from main text: "nefs-i Pazar-i $\mathrm{H}(\mathrm{v})$ oça":

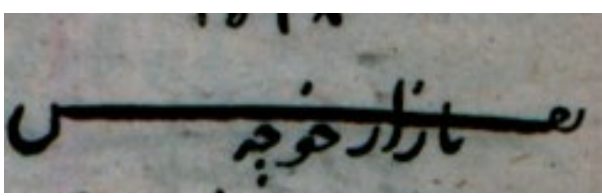

O.76, fol. 37b, from main text: "tabi-i $\mathrm{H}(\mathrm{v})$ oça":

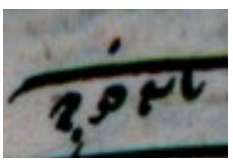

And for comparison, also from main text: O.76, fol. 132b: "Hum":

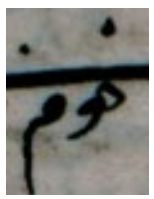

It is not uncommon to find references in O.76 for fortress personnel to have surrendered their fortresses to the new Ottoman masters, like Ivaniš and Stipan 
the fortress of Doboj (fol. 48a), Knez Radoja Zupčić the fortress of Sokol (fol. 67b), Isa Bali (who accepted Islam) the fortress of Samobor (fol. 74b), Mahmud (who accepted Islam) the fortress of Nevesinje (fol. 90a), Macar Mahmud (who evidently also converted to Islam) the fortress of Novi (fol. 125b, the latter three all in Hercegovina) and Karaca the fortress of Skadar (fol. 142b). Pavao Grgurić now appears to have surrendered two strongholds one after the other in close succession, yet remaining a Christian: Travnik (probably in May 1463), ${ }^{14}$ and (it now seems) Foča two years afterwards, at the latest.

(3) Was Pavao Grgurić indeed finally taken prisoner (see the secondary reference)? The original wording in $\mathrm{O} .76$ has the following (fol. 59b):

bi-emr-i padişabla [written prominently] mezkur dutsak oldiğı sebebden bu köy Haydara bi-emr-i padişah verildi (...)", which I take to mean "because the aforementioned was detained by decree of the padishah, this village [Homolje] was by decree of the padishah given to Haydar (...)

Rather than having been taken prisoner by the enemy, he appears to have been detained (tutsak) on account of a sultanic order. The relevant marginal note (derkenar) is dated Istanbul, 23 Zilkade 881 (9 March 1477).

The picture which emerges from the re-visited evidence perhaps poses more questions than it can answer, but it nevertheless allows us to discuss some of the principal features in the career of a man who offered his services first to the Bosnian king Stjepan Tomašević, shortly thereafter (so it seems) to herceg Stjepan Vukčić Kosača of Hercegovina, and finally to Sultan Mehmed II before being removed from the scene by the Conqueror himself, but only after a career in the Ottoman ranks that spanned at least a dozen years.

Despite the fact that the survey register entry quoted above mentions the fortress of Travnik only as the second stronghold surrendered by Pavao Grgurić, our understanding of the chronology of events during the turbulent years of the 'silent' fall to the Ottomans of the kingdom of Bosnia, incomplete as it certainly is, would suggest that he served in Travnik first. That it was he who 'surrendered' the fortress is clear from the wording employed in defter $\mathrm{O} .76$ which uses the participle of the verb 'to give, hand over' (veren) ${ }^{15}$ like in all other instances of people handing over to the Ottomans Christian-held strongholds. ${ }^{16}$ If we are to believe Hazim

$14 \quad$ Hazim Šabanović, Bosanski pašaluk (Sarajevo, 1982), 38.

15 “(...) H(v)oca ve Travnik hisarları veren Pave Grguriğe verildi." O.76, fol. 59b.

16 O. 76, Fols. 48a, 67b, 74b, 90a, 100a, 125b, 142b. 
Šabanović, Travnik fell in May 1463 (see above). The accepted date for the fall of Foča to the Ottoman forces is given by the same authority as 'spring $1465^{\prime} ;{ }^{17}$ but two derkenars recorded in the icmal survey register published by Hazim Šabanović ${ }^{18}$ were executed 'in the camp of Foča' on 2 July 1463, a fact which Šabanović is not, however, inclined to consider as evidence for a possible earlier surrender of Foča to the Ottoman forces. Whatever the actual date of Pavao's involvement here, it is a matter for future investigations to establish how it was possible for one of the king's fortress commanders to surrender one fortress to the Ottomans before getting a new command elsewhere defending another Christian lord, this time, apparently, in Hercegovina. Yet it is highly probable that Pavao Grgurić had indeed served the Ottomans well twice before he was granted a timar, albeit a timar with several highly unusual features:

The 14 villages in the vicinity of Hum fortress assigned to him as a timar are all listed in $\mathrm{O} .76$ as hali ('empty', 'unoccupied', 'deserted'), with accordingly no income figures ( hasil) indicated. The word 'hali' set against every single one of his villages is generally taken to mean 'deserted' (this also is Alićić's interpretation), but one must keep in mind the possibility of it meaning 'void of any hasil figure', suggesting, for example, sources of income not yet assessed for their hasll value. In a survey register that has no predecessor, but is the first to have been executed for the area in question, this would be the equivalent of a haric ez defter ("not in the [previous] survey register') recording.

It may be significant that the 14 villages in question are densely spread over and around the Tribanj area overlooked by the fortress of Hum, ${ }^{19}$ of which some architectural features remain to this day. Together they form a group of villages and hamlets which constitute a cluster of settlements stretching across the hilly terrain above the plains of Livanjsko polje and Buško blato while facing the Kamešnica massif in the south-west, constituting an area through which since Roman times the principal road from Split led into the interior of Bosnia. By 1468/69, this cluster of villages must have marked the westernmost extent of Ottoman control, if indeed they (still) were under Ottoman (military) control by the time O.76 was completed. In fact, it may be questionable whether they ever fully came under Ottoman (administrative) control during the $15^{\text {th }}$ century. It therefore may have been the absence of full Ottoman administrative control over the villages and hamlets granted as a timar to Pavao Grgurić which led to their recording as 'void of any hasil figure' - unless one believes like most researchers have done that every one

17 Šabanović, Bosanski pašaluk, 37 dates the fall of Foča to 'spring 1465'.

18 Hazim Šabanović, Krajište Isa-bega Ishakovića. Zbirni katastarski popis iz 1455. godine (Sarajevo, 1964), 68.

19 Perković, “Livanjski kraj”, 320ff. 
of the cluster of 14 village and hamlet in the (wider) Tribanj area by 1468/69 lay empty and deserted to the last man, with not a single exception.

Another fact which singles out the timar of Pavao Grgurić has already been mentioned: While most other larger timars in the sanjak of Bosna are constituted of villages (or parts of villages) which are (geographically) often considerably spaced apart, his is based on a contiguous group of settlements. Is this a mere coincidence, or are we dealing here with the remnants of pre-Ottoman 'feudal' structures, such as a 'Burgbezirk' or cluster of settlements under the authority of a castle in the hands of a feudal lord? If the latter were the case, we might perhaps have found an explanation for the limited Ottoman administrative 'grip' on the resources of this particular group of villages, if this is what the term 'empty' signifies. What would be significant in such a case is that a more detailed assessment of the area's tax resources would still have eluded the Ottoman fiscal authorities several years after the area's (initial) conquest.

Another feature which distinguishes the timar of Pavao Grgurić from most, if not all other (larger) timars in the sanjak of Bosna is that it is granted him at the rate of zero income (i.e. no hastl indicated). He is said in $\mathrm{O} .76$ just to hold a timar of 14 villages. Significantly, there are no specific military obligations mentioned alongside this timar in the survey register, except that he 'guards the fortress by the name of HUM in the nabiye of Hlivno'. What, one might ask, would then have been the benefit to the timar owner of holding a timar of 'deserted' villages with no income, unless the villagers could be expected soon to return (or to be replaced by new manpower in due course), or else surveyed for tax purposes without delay, thereby securing the timar owner's income - unless the timar owner in question had already secured himself access to the resources of the area with the tacit consent of officialdom. It has long been known that large swathes of Ottoman Bosnia remained outside the timar system's application, continuing pre-Ottoman (military and social) forms of organization, particularly in predominantly Vlach inhabited areas. In the case of Pavao Grgurić, however, we do seem to observe some form of application of the timar system - at least in name. But had it also been applied in substance? Remember, there is no fixed recorded income, nor any specific indication of military obligations. Why though apply the timar system in name only? The answer most likely lies in the Ottoman practice of incorporating pre-Ottoman 'feudal' structures into the Ottoman prebendal system by means of a timar wherever feasible. For example, when the baštinas of the (Christian) kadimî sipabis (preOttoman feudal landed horsemen) called Pribić, son of Priboje and his brother Pribašin in Bribičko, Zastenje and Kutjezero villages in Vratar district were entered into O.76, they were recorded as a timar without revenue figures, but with the obligation to serve. ${ }^{20}$ The village of Podsol in Osad district was awarded (without

20 Aličić, Sumarni popis, 132. 
any revenue figures) to (the Christian) Radojin Batević with the sole obligation to cultivate and populate the village which was presently haric ez defter ('not in the [previous] survey register') ${ }^{21}$ It may have been a similar arrangement on which the timar of Pavao Grgurić was based.

Pavao Grgurić - was he originally a feudal lord (cum castellan?) in the Tribanj area below Hum fortress turned possessor of a timar by the new Ottoman masters to accommodate him within the Ottoman fortress command structure? It may be significant that the defter $\mathrm{O} .76$ would record his timar between the timars belonging to the personnel of Bobovac fortress and those in the hands of the personnel of Hodidide fortress. ${ }^{22}$ His job, like that of his Muslim colleagues, perhaps was to serve, despite his previous loyalties, as the Christian defender of Hum fortress in the service of the Sultan, drawing on the resources from the villages of his (ancestral or assigned) 'Burgbezirk' in the (wider) Tribanj area belonging to the district of Hlivno.

Whatever his exact de-facto annual revenue from the cluster of villages in the Tribanj area, Pavao Grgurić was soon to hold a substantial timar elsewhere in Ottoman Bosnia: After Davud, a brother of Skender voyvoda, became the chief commander (ser-asker) of Saray-ovası district, his timar that was originally held by a certain Mahmud Diraz in the Konjic/Rama area (including the village of Gorani near Konjic) was transferred to Pavao Grgurić, together ('combined') with that of Homolje, also situated near Konjic. ${ }^{23}$ Taken together, the combined revenue amounted to 25,705 akçe from 182 households, 30 bachelors and two widows, a very considerable assignment. ${ }^{24}$ His personal military obligations, indicated for the first time, are equally substantial: He was to appear personally as a horseman in armour (bürüme), followed when called to arms by five armed and equipped servicemen (cebelü), one servant (gulam) and a tent (see above). Unfortunately, O.76 does not offer a dated derkenar for this transfer, but we know that the timar originally held by Mahmud Diraz (who is said to have fled to the unbelievers) was awarded to Davud on 7 April 1470, while another timar in the Kakanj area (already) in the hands of Davud, brother of Skender voyvoda, is transferred by means of a derkenar dated between 13 and 22 April 1470 to a certain Ismail on the grounds of Davud already holding another timar elsewhere. ${ }^{25}$ This means that Pavao Grgurić can only have been awarded his (combined) timar after this date. Exactly how much later is

\footnotetext{
Loc.cit.

Aličić, Sumarni popis, 193-202.

Aličić, Sumarni popis, 100, 102.

24 For comparison: Kara Balaban, ser-asker of Brod, Bobovac, Visoka, Lašva and Kreševo, draws on a revenue of 17,937 akçe from 113 households and 15 bachelors, augmented to 21,037 akçe: Aličić, Sumarni popis, $77 \mathrm{f}$.

25 Lo.cit., 88.
} 
difficult to establish with certainty, unless we identify Davud with Davud, voyvoda of Saray-ovas1, who replaced Skender voyvoda who had been in this position from 1463. Vesna Mušeta-Aščerić appears to date the change from Skender to Davud voyvoda to as early as 8 April $1470 .{ }^{26}$

A marginal note (derkenar) in 0.76 marks the end of Pavao's career in Ottoman service, at least for the time being. "Because the aforementioned was, by means of a decree of the padishah (highlighted in bold letters, or else inserted at some later stage), detained (dutsak), this village [Homolje] was given by order of the padishah to Haydar who serves. [Written] on 23 Zilkade 881 in Istanbul" (fol. 59b). The corresponding Gregorian date is 9 March 1477. It is thanks to the derkenar already discussed further above that we can suggest a more precise date for Pavao's detention: The marginal notes which accompany the entry of Mahmud Diraz's timar hold yet another piece of evidence: Following the derkenar that this timar is in the hands of 'the Christian by the name of Pavao Grguric', it is stated by a different hand that it was given, by order of the padishah, without augmentation, to the Christian by the name of Filip, ${ }^{27}$ on condition that he serves. The date: 28 Ramazan 881 (14 January 1477), in the camp of Niš. It would appear that Pavao Grgurić was detained by decree of Sultan Mehmed not long before this date, after which part of his substantial timar was awarded to another Christian sipahi.

At this stage of our knowledge we can only speculate what made the Sultan have his long-standing Christian 'man of the sword' arrested on his own order. Pavao Grgurić had served his master for many years in his capacity as a Christian sipahi holding a double timar which was exceptionally large $(25,705 a k c ̧ e)$ by the standards of a Christian sipahi, but also in comparison with the incomes of Muslim timar holders it must be considered unusually substantial. While the zeamet of Mehmed Çelebi, son of Isa Beğ, comprising the entire Pavlović vilayet had a recorded computed income of 73,460 ? akçe, ${ }^{28}$ the revenue recorded in 0.76 for the zeamet possession of Hasan Beğ only amounted to 18,099 akçe..$^{29}$ The vast majority of timars listed in this survey register came with an income of far less than 9,000 akçe, with very many below 3,000. It is interesting to note that while Mehmed Çelebi's military obligations included the provision for two tents to house the 18 cebelü he was to lead while on campain, Hasan Beğ had to provide four cebelüs, one fewer than Pavao Grgurić. The latter's (military) role was clearly significant even when compared with that of beğs. Whatever other roles, if any, he might have played as a Christian

\footnotetext{
26 Vesna Mušeta-Aščerić, "Sarajevo - od kasabe do šehera”, in: Eadem., Sarajevo i okolina u XV stoljeću: izmedju zapada i istoka (Sarajevo, 2005), 143-97; here: 168.

27 For (this?) Filip also see Aličić, Sumarni popis, 108 (derkenar dated 2 Şaban 881); p. 200 (derkenar dated 11 Şaban 882).

28 Aličić, Sumarni popis, 72-74.

29 Aličić, Sumarni popis, 74.
} 
in Ottoman services vis-à-vis the 'puppet' Kotromanić kingdom of Bosnia under Ottoman suzerainty since its re-foundation late in 1465 is unclear, but it may be no coincidence that he was detained, evidently not long before 14 January 1477 , that is shortly after we hear of the Bosnian king Matija Vojsalić for the last time (by 3 July 1476). Both Pavao Grgurić and the last Bosnian kingdom appear to have vanished from the pages of history at much the same time. ${ }^{30}$

\section{CONCLUSION}

There is an urgent need for bringing back the individual into the writing of Ottoman (provincial) history, without losing sight of the institutional implications of our findings as we go along. It would seem particularly rewarding to trace through space and time by means of a case-study individuals who, in their careers, have successfully negotiated the transition from pre-Ottoman to Ottoman rule, or from the Abode of War into the Abode of Islam (or vice-versa). Pavao Grgurić is but one example for the first category, while certain friars (Franciscan, Benedictine), particularly of the early period, as well as renegades like Macar Mahmud, are examples for the second. It should have become clear from the present study just how important, alongside the far better known type of detailed (mufassal) Ottoman tapu tabrir defteri, is the summary (icmal) type for establishing a detailed chronology of events between the irregularly spaced intervals of province-wide surveys.

\section{BIBLIOGRAPHY}

\section{UNPUBLISHED ARCHIVAL SOURCES}

Atatürk Kitaplığı, Istanbul. Survey register O.76.

\section{PUBLISHED SOURCES AND LITERATURE}

Aličić, Ahmed A.. Sumarni popis sandžaka Bosna iz 1468/69. godine. Mostar, 2008. Mušeta-Aščerić, Vesna. "Sarajevo - od kasabe do šehera." In: Eadem., Sarajevo $i$ okolina u XV stoljeću: izmedju zapada i istoka. Sarajevo, 2005, 143-97.

Perković, Tomislav. "Livanjski kraj u doba rane osmanske vladavine." CLEUNA 1 (2014): 284-380.

Šabanović, Hazim. Bosanski pašaluk. Sarajevo, 1982.

30 Šabanović, Bosanski pašaluk, 48f. 
Šabanović, Hazim. Krajište Isa-bega Ishakovića. Zbirni katastarski popis iz 1455. godine. Sarajevo, 1964.

Salihović, Davor. "Definition, Extent, and Administration of the Hungarian Frontier Toward the Ottoman Empire in the Reign of King Matthias Corvinus, 1458-1490." Unpublished PhD thesis, Magdalene College, Cambridge, 2020.

Ursinus, Michael. “Ivan Ljubunčić, Frančesko Čubranić i Matij Hrvat[inić]: Davudpašini livanjski ratni zarobljenici iz godine1480." CLEUNA 4 (2021): 97 107. 